\title{
Formation of Copper Oxide Nanotextures on Porous Calcium Carbonate Templates for Water Treatment
}

\author{
Mahmud Diab ${ }^{1,+}{ }^{,}$Karam Shreteh ${ }^{1}\left(\mathbb{D}\right.$, Michael Volokh $^{1}(\mathbb{D})$ and Taleb Mokari ${ }^{1,2, *}$ \\ 1 Department of Chemistry, Ben-Gurion University of the Negev, Beer-Sheva 8410501, Israel; \\ diabmah@post.bgu.ac.il (M.D.); shreteh@post.bgu.ac.il (K.S.); volokh@bgu.ac.il (M.V.) \\ 2 Ilse Katz Institute for Nanoscale Science and Technology, Ben-Gurion University of the Negev, \\ Beer-Sheva 8410501, Israel \\ * Correspondence: mokari@bgu.ac.il \\ † Current address: The Institute of Applied Research, The Galilee Society, Shefa-Amr 20200, Israel.
}

Citation: Diab, M.; Shreteh, K.;

Volokh, M.; Mokari, T. Formation of Copper Oxide Nanotextures on Porous Calcium Carbonate Templates for Water Treatment. Molecules 2021, 26, 6067. https://doi.org/10.3390/ molecules26196067

Academic Editor: Irina Savina

Received: 13 September 2021

Accepted: 5 October 2021

Published: 7 October 2021

Publisher's Note: MDPI stays neutral with regard to jurisdictional claims in published maps and institutional affiliations.

Copyright: (c) 2021 by the authors. Licensee MDPI, Basel, Switzerland. This article is an open access article distributed under the terms and conditions of the Creative Commons Attribution (CC BY) license (https:/ / creativecommons.org/licenses/by/ $4.0 /)$.

\begin{abstract}
The necessity of providing clean water sources increases the demand to develop catalytic systems for water treatment. Good pollutants adsorbers are a key ingredient, and $\mathrm{CuO}$ is one of the candidate materials for this task. Among the different approaches for $\mathrm{CuO}$ synthesis, precipitation out of aqueous solutions is a leading candidate due to the facile synthesis, high yield, sustainability, and the reported shape control by adjustment of the counter anions. We harness this effect to investigate the formation of copper oxide-based 3D structures. Specifically, the counter anion (chloride, nitrate, and acetate) affects the formation of copper-based hydroxides and the final structure following their conversion into copper oxide nanostructures over porous templates. The formation of a 3D structure is obtained when copper chloride or nitrate reacts with a Sorites scaffold (marine-based calcium carbonate template) without external hydroxide addition. The transformation into copper oxides occurs after calcination or reduction of the obtained $\mathrm{Cu}_{2}(\mathrm{OH})_{3} \mathrm{X}\left(\mathrm{X}=\mathrm{Cl}^{-}\right.$or $\left.\mathrm{NO}_{3}{ }^{-}\right)$while preserving the porous morphology. Finally, the formed Sorites@CuO structure is examined for water treatment to remove heavy metal cations and degrade organic contaminant molecules.
\end{abstract}

Keywords: copper oxide; 3D structure; heavy metal; water purification; Sorites; microorganism template; pollutant decontamination

\section{Introduction}

In spite of the tremendous progress in technology, science, and medicine, nowadays, millions of people still do not have access to a clean water source [1]. For this reason, several approaches were developed for water purification, relying on activated carbon, reverse osmosis, ion exchange, distillation, and others [2-8]. Furthermore, a lot of effort is invested in seeking the best candidate materials. Metal oxides, such as $\mathrm{TiO}_{2}, \mathrm{Fe}_{2} \mathrm{O}_{3}, \mathrm{MnO}_{2}, \mathrm{CeO}_{2}$, $\mathrm{MgO}, \mathrm{CuO}$, and others, were extensively used in various water purification processes due to their properties, specifically, high sorption capacity, high stability, abundance, low cost, and low toxicity [9-14]. All purification techniques benefit from using materials with a large surface area-to-volume ratio. In such cases, a significant fraction of their active sites is exposed, which, in turn, facilitates contaminants' adsorption (and possibly their decomposition in a secondary step). Developing materials with hierarchical structures can markedly improve the purification performance. A three-dimensional (3D) design increases the surface-to-volume ratio significantly (vs. a 2D design) and grants the possibility of interaction between the pollution (the adsorbate) and the active material (the adsorbent, acting as the filter).

Recently, $\mathrm{CuO}$ has attracted particular attention of the water purification community because of its antimicrobial properties, capability for driving dye degradation reactions, high sorption capacity for heavy metal ions (for instance, $\mathrm{As}(\mathrm{III})$ and $\mathrm{As}(\mathrm{V}), \mathrm{Pb}(\mathrm{II}), \mathrm{Cd}(\mathrm{II})$, and $\mathrm{Cr}(\mathrm{VI})$ [13-16]. A ceramic membrane that incorporates a $\mathrm{CuO}$ active material rejects 
more than $97.14 \%$ of $\mathrm{Pb}$ (II) and $91.44 \%$ of $\mathrm{Cr}$ (VI) [17,18]. Moreover, $\mathrm{CuO}$ nanowires show promising activity in oil-water separation [19]. Several reported works evaluated the $\mathrm{CuO}$ activity for methylene blue (MB) oxidation in the presence of hydrogen peroxide in aqueous solutions $[20,21]$. $\mathrm{CuO}$ is also photocatalytically active, allowing harnessing a radicalbased mechanism for organic contaminants degradation and antibacterial performance. For example, the degradation of methyl orange was completed using $\mathrm{CuO}$ catalyst via photogenerated $\cdot \mathrm{OH}$ radicals [22]. Additionally, hydrogen peroxide $\left(\mathrm{H}_{2} \mathrm{O}_{2}\right)$ was used, in the presence of $\mathrm{CuO}$, to increase the radicals' production rate by more than one order of magnitude [23]. This combination was successfully examined in the degradation of a brominated flame retardant [24] and to improve the antibacterial performance of $\mathrm{CuO}$ versus (vs.) E. coli [23]. Furthermore, the antibacterial activity of $\mathrm{CuO}$ vs. E. coli and S. aureus was found to be size-dependent- the smaller the $\mathrm{CuO}$ particles are, the higher their antibacterial activity becomes [25].

The progress in the synthesis of $\mathrm{CuO}$ manifests in the variety of shapes and sizes that have been reported via different approaches. For example, nanoparticles (sonochemical [26], precipitation [27]), nanorods (hydrothermal) [24,28], 3D structures (templates as mesoporous silica KIT-6 [29], copper foam [30], or anodic aluminum oxide [31]), thin films (chemical vapor deposition) [32], and close-packed films (combination of thermal decomposition and oxidation) [33] were reported. However, there is a lingering need to develop methods that tackle specific disadvantages of the previously mentioned approaches. For instance, when two separate steps are utilized (e.g., first formation and then assembly of particles), it complicates integration into devices. The fabrication of 3D structures either uses small templates that must be assembled on a supporting substrate, resulting in the loss of a high percentage of its total surface area, or the templates are difficult to remove (while preserving the morphology).

Herein, we demonstrate a facile method to form a porous structure of $\mathrm{CuO}$ via a two-step reaction. First, a copper-based hydroxide 3D structure is prepared by reacting a copper salt with a calcium carbonate template without hydroxide salt addition (the chosen template is Sorites - a marine calcareous foraminiferal shell of few mm diameter [34]). Subsequently, the obtained structure undergoes a reduction or calcination process to form Sorites@Cu $\mathrm{Cu}_{2} \mathrm{O}$ or Sorites@CuO, respectively. Sorites consists mainly of $\mathrm{CaCO}_{3}$, which is easy to remove using a mild acid. In addition to the net-like structure, the Sorites has internal tunnels that connect its holes. We believe that these tunnels may confine the reactants, which increases the collision probability of the reactant molecules, and in turn, improves the performance of the active material [34-36].

Furthermore, it was reported that the nature of the counter anion of the copper complex (such as $\mathrm{Cl}^{-}, \mathrm{SO}_{4}{ }^{2-}, \mathrm{NO}_{3}{ }^{-}$, and $\mathrm{CH}_{3} \mathrm{COO}^{-}$) has a direct influence on the size, shape, and crystal structure of the hydroxide product [37-40]. However, to the best of our knowledge, there is no report discussing the effect of the counter anion on the formation of a $3 \mathrm{D}$ structure. Therefore, three different $\mathrm{Cu}$ (II) salts- $\mathrm{CuCl}_{2}, \mathrm{Cu}\left(\mathrm{NO}_{3}\right)_{2}$, and $\mathrm{Cu}(\mathrm{ac})_{2}$-were used to elucidate their role in the formation of the 3D structure. Finally, we examine the performance of the prepared $\mathrm{CuO}$ 3D structures for water treatment, specifically for heavy metal ions removal and for the degradation of contaminant organic dyes as methylene blue.

\section{Results and Discussion}

To form the hereinafter reported 3D porous structures, Sorites scaffolds of marine origin were cleaned and assembled perpendicularly on a substrate using carbon tape, as shown in Figure 1a. The substrate was then immersed into the reaction vessel containing the $\mathrm{Cu}$ (II) salt to form the copper hydroxide-based coating (Figure 1b). See more details in the Materials and Methods (Sections 3.2 and 3.3). 

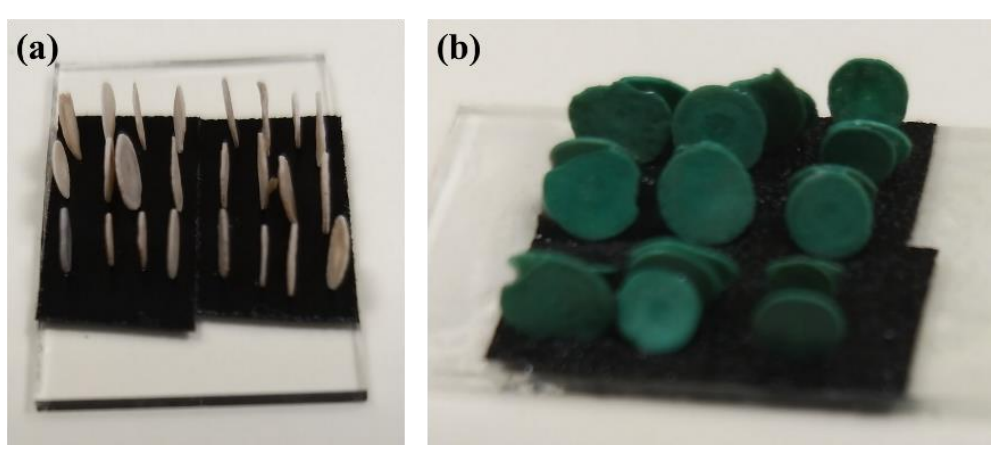

Figure 1. Optical images of the Sorites before (a) and after (b) reacting with $\mathrm{CuCl}_{2}$ to form a $3 \mathrm{D}$ structure of copper-based hydroxide.

\subsection{Formation of 3D Structures of Sorites@Copper-Based Hydroxide Using Various Copper Salts}

Figure 2 shows optical and scanning electron microscopy (SEM) images of the Sorites before $(\mathrm{a}-\mathrm{d})$ and after reacting with $\mathrm{CuCl}_{2}(\mathrm{e}-\mathrm{h}), \mathrm{Cu}\left(\mathrm{NO}_{3}\right)_{2}(\mathrm{i}-\mathrm{l})$, and $\mathrm{Cu}(\mathrm{ac})_{2}(\mathrm{~m}-\mathrm{p})$ at $120^{\circ} \mathrm{C}$ for $45 \mathrm{~min}$ (details in the experimental section). The optical images of the Sorites structures dramatically change before and after reacting with the copper salt, from white to turquoise, respectively. Furthermore, the visual images confirm that the morphology of the Sorites structure is well-kept when Sorites react with $\mathrm{CuCl}_{2}$ and $\mathrm{Cu}\left(\mathrm{NO}_{3}\right)_{2}$ to form the 3D structure of copper-based hydroxide. The SEM images present the homogeneity of the formed shell and show that the shell layer consists of particles with a typical size of a few hundred nm. Furthermore, the SEM images of the cross-section view (Figure 2d,h,l) show evidence of coating the internal surface of the Sorites structure. When $\mathrm{Cu}(\mathrm{ac})_{2}$ was used, the template morphology was preserved, but an aggregation of copper acetate was formed and precipitated on the surface of the Sorites, as portrayed in the SEM images in Figure $2 n-p$.

The difference in the quality of the formed shell layer between the three copper salts can be attributed to the acidity of the growth solution. $\mathrm{CuCl}_{2}$ and $\mathrm{Cu}\left(\mathrm{NO}_{3}\right)_{2}$ dissolve in water to give an acidic growth solution $(\mathrm{pH} \approx 4)$, while $\mathrm{Cu}(\mathrm{ac})_{2}$ provides a milder one ( $\mathrm{pH} \approx 6$, due to hydrolysis of the acetate conjugate base). The acidity of the growth solution plays an important role, particularly in our case, when Sorites is used (as this template consists of $\mathrm{CaCO}_{3}$ ). The solubility of $\mathrm{CaCO}_{3}$ significantly increases with increasing solution acidity. The $\mathrm{K}_{\mathrm{sp}}$ of $\mathrm{CaCO}_{3}$ (calcite phase) at $25^{\circ} \mathrm{C}$ is $3.36 \times 10^{-9}$, and the $\mathrm{p} \mathrm{K}_{\mathrm{a}}$ of $\mathrm{H}_{2} \mathrm{CO}_{3}$ is 6.35 [41]. The $\mathrm{pH}$ of the growth solution must be low enough to diminish the homogenous nucleation of a copper hydroxide precipitate in the solution and high enough to retain the $3 \mathrm{D}$ structure of the $\mathrm{CaCO}_{3}$ template. We found that the shell formation was better when the $\mathrm{pH}$ of the growth solution was about four. This result is attributed to the improvement in the dissolution rate of the $\mathrm{CaCO}_{3}$ surface in solutions that contain the chloride or the nitrate counter anions rather than the acetate, as discussed below (Equations (1)-(3)). Furthermore, we believe that the dissolution of the Sorites' surface increases the surface roughness, which, in turn, acts as a nucleation site for the copper hydroxide shell formation.

To further investigate the effect of the counter anion, structural characterization was conducted by X-ray diffraction, as shown in Figure 3. In all three cases, the obtained diffraction patterns match a rhombohedral $\mathrm{Mg}_{0.1} \mathrm{Ca}_{0.9} \mathrm{CO}_{3}$ (JCPDS card no. 071-1663) and the formation of additional diffraction signals, which can be assigned to the Sorites and copper-based hydroxide, respectively. Figure $3 \mathrm{a}, \mathrm{b}$ shows that the reaction between Sorites and $\mathrm{CuCl}_{2}$ or $\mathrm{Cu}\left(\mathrm{NO}_{3}\right)_{2}$ forms an orthorhombic copper(II) hydroxychloride $\left(\mathrm{Cu}_{2} \mathrm{Cl}(\mathrm{OH})_{3}\right.$, JCPDS card no. 071-2027), or monoclinic copper(II) hydroxynitrate $\left(\mathrm{Cu}_{2}(\mathrm{OH})_{3} \mathrm{NO}_{3}\right.$, JCPDS card no. 075-1779), respectively. When the Sorites reacts with $\mathrm{Cu}(\mathrm{ac})_{2}$, no copper hydroxide is found in the final product, and the diffraction pattern of $\mathrm{Cu}(\mathrm{ac})_{2}$ hydrate (JCPDS card no. 010-0756) best matches the obtained XRD pattern, as presented in Figure 3c, though this diffraction is weak and may indicate only partial crystallinity. 

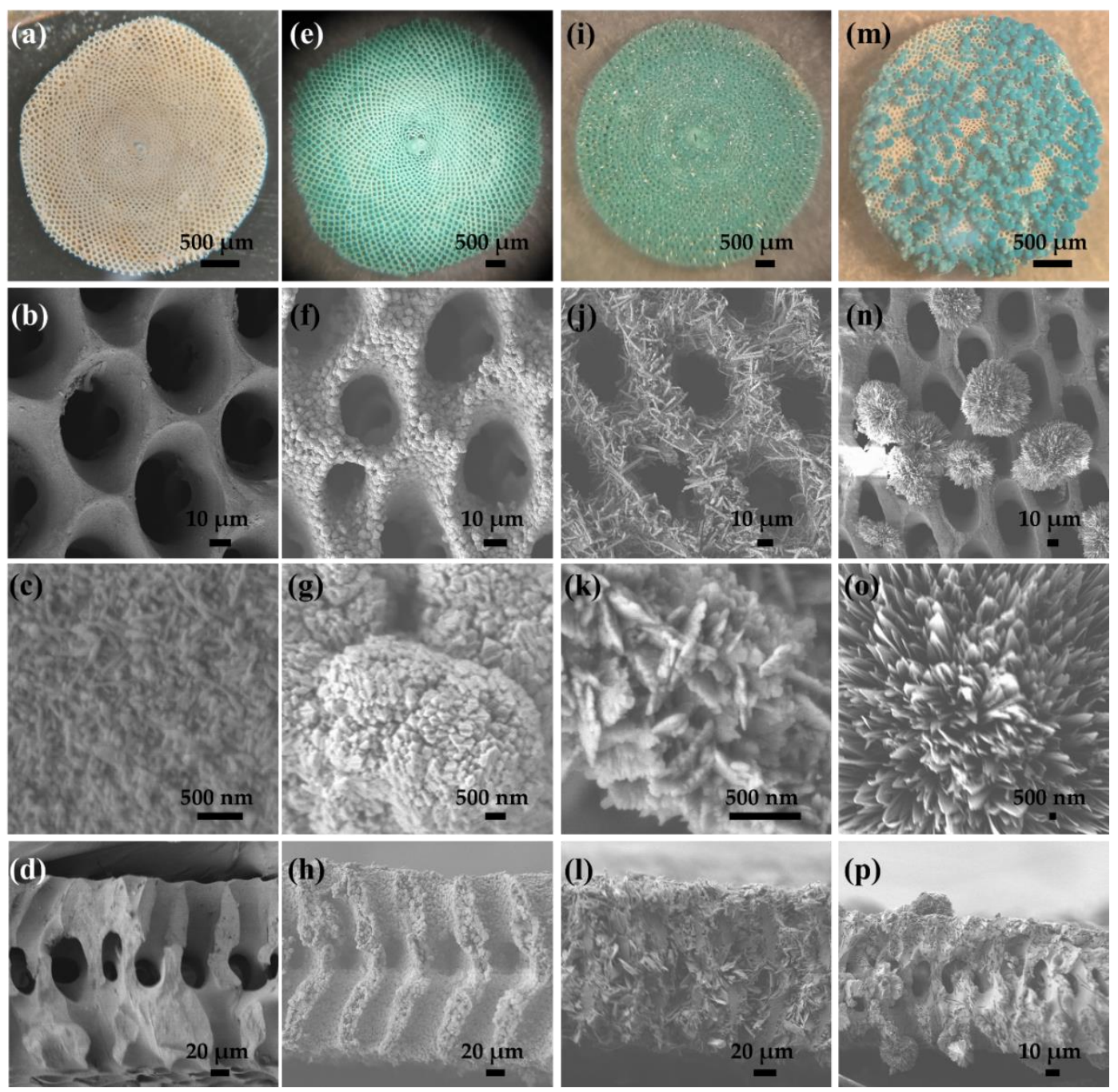

Figure 2. Optical and scanning electron microscopy (SEM) images of the Sorites 3D structure before (left column, a-d) and after reacting with three different copper salts (the subsequent columns from left to right): $\mathrm{CuCl}_{2}(\mathbf{e}-\mathbf{h}), \mathrm{Cu}\left(\mathrm{NO}_{3}\right)_{2}(\mathbf{i}-\mathbf{l})$, and $\mathrm{Cu}(\mathrm{ac})_{2}(\mathbf{m}-\mathbf{p})$. (a,e,i,m) optical images, SEM top-view images, and SEM cross-section images $(\mathbf{d}, \mathbf{h}, \mathbf{l}, \mathbf{p})$.

Usually, to form a $\mathrm{Cu}(\mathrm{OH})_{3} \mathrm{X}\left(\mathrm{X}=\mathrm{Cl}^{-}, \mathrm{NO}_{3}{ }^{-}, \mathrm{CH}_{3} \mathrm{COO}^{-}\right.$, and others $), \mathrm{CuX}_{2}$ reacts with a hydroxide source (such as $\mathrm{NaOH}$ or $\left.\mathrm{Mg}(\mathrm{OH})_{2}\right)[38,40]$. However, in the reported approach, $\mathrm{Cu}(\mathrm{OH})_{3} \mathrm{Cl}$ and $\mathrm{Cu}(\mathrm{OH})_{3} \mathrm{NO}_{3}$ are formed by reacting the $\mathrm{CuX} X_{2}$ with the Sorites (the template) without adding a hydroxide salt. We think that the Sorites template is also responsible for the formation of the required hydroxide anions through the proposed mechanism:

$$
\begin{gathered}
\mathrm{CaCO}_{3}(\mathrm{~s})+\mathrm{H}_{3} \mathrm{O}^{+}(\mathrm{aq}) \rightleftharpoons \mathrm{Ca}^{2+}(\mathrm{aq})+\mathrm{HCO}_{3}^{-}(\mathrm{aq})+\mathrm{H}_{2} \mathrm{O}(\mathrm{l}) \\
\mathrm{HCO}_{3}^{-}(\mathrm{aq})+\mathrm{H}_{2} \mathrm{O}(\mathrm{aq}) \rightleftharpoons \mathrm{OH}^{-}(\mathrm{aq})+\mathrm{H}_{2} \mathrm{CO}_{3}(\mathrm{aq}) \\
2 \mathrm{Cu}^{2+}(\mathrm{aq})+3 \mathrm{OH}^{-}(\mathrm{aq})+\mathrm{X}^{-} \rightarrow \mathrm{Cu}_{2}(\mathrm{OH})_{3} \mathrm{X}(\mathrm{s})
\end{gathered}
$$

In the first stage, due to the acidity of the growth solution $(\mathrm{pH} \approx 4)$, the $\mathrm{CaCO}_{3}$ surface dissolves to form $\mathrm{HCO}_{3}{ }^{-}$(aq). Subsequently, the bicarbonate undergoes a hydrolysis reaction to produce $\mathrm{OH}^{-}(\mathrm{aq})$, and in the final step, the copper salt reacts with the produced hydroxide to form the $\mathrm{Cu}_{2}(\mathrm{OH})_{3} \mathrm{X}$. The proposed mechanism explains well the uniformity of the formed shell. Notably, the shell coats well the internal surface of the template, as presented in the cross-section images in Figure $2 \mathrm{~h}, \mathrm{l}$, when $\mathrm{CuCl}_{2}$ and $\mathrm{Cu}\left(\mathrm{NO}_{3}\right)_{2}$ were used. 
The $\mathrm{OH}^{-}(\mathrm{aq})$ is formed close to the template's surface, where $\mathrm{Cu}_{2}(\mathrm{OH})_{3} \mathrm{X}$ precipitates to form the shell layer. The fact that using $\mathrm{Cu}(\mathrm{ac})_{2}$ does not form a $\mathrm{Cu}_{2}(\mathrm{OH})_{3}\left(\mathrm{CH}_{3} \mathrm{COO}\right)$ and the coating is not uniform, as presented in Figure $2 \mathrm{~m}-\mathrm{p}$, supports the proposed mechanism as the growth solution is not acidic enough to drive Reaction 1.
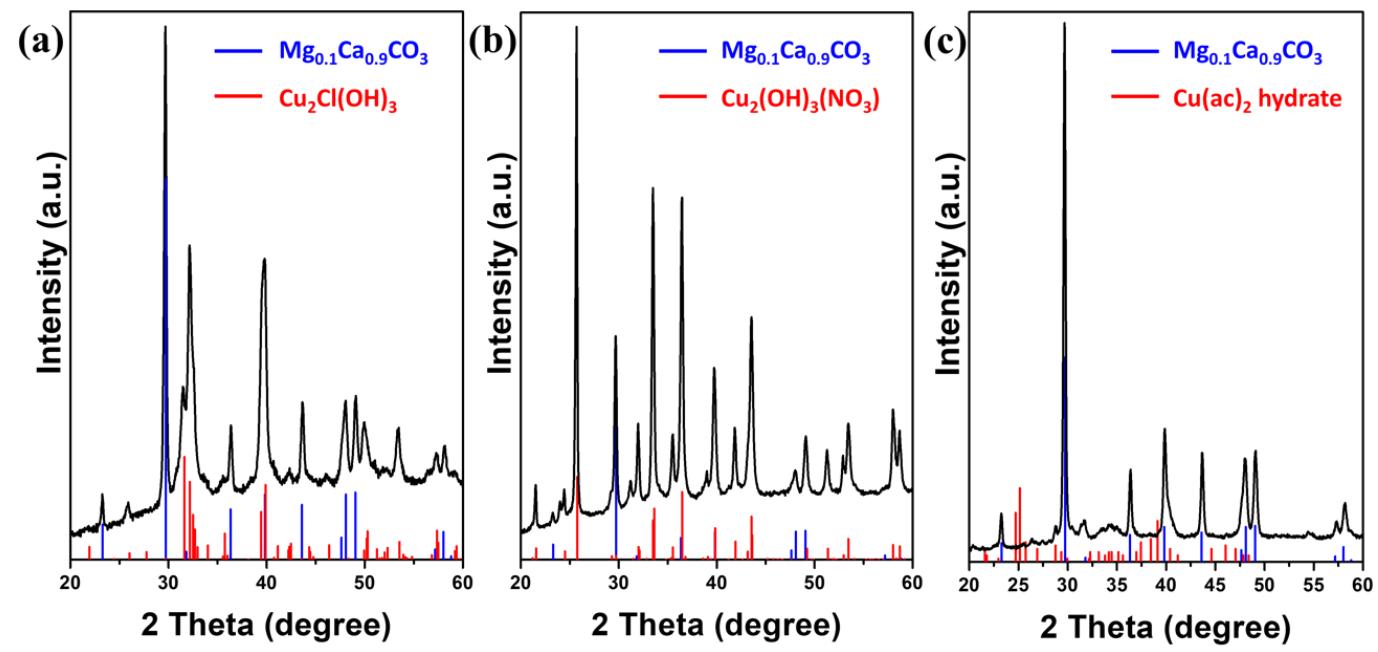

Figure 3. X-ray diffraction patterns of the 3D structures after reacting Sorites with different copper salts. (a) Sorites@ $\mathrm{Cu}_{2} \mathrm{Cl}(\mathrm{OH})_{3},\left(\right.$ b) Sorites@ $\mathrm{Cu}_{2}(\mathrm{OH})_{3}\left(\mathrm{NO}_{3}\right)$, and (c) Sorites decorated with $\mathrm{Cu}(\mathrm{ac})_{2}$ hydrate. The blue and red bars in the XRD panels correspond to the rhombohedral $\mathrm{Mg}_{0.1} \mathrm{Ca}_{0.9} \mathrm{CO}_{3}$ and the coated material, respectively.

\subsection{Using Sorites@Cu $\left.\mathrm{Cl}_{2} \mathrm{OH}\right)_{3}$ as a Prototype to Further Investigate the Coating Process and Their Conversion to Sorites@CuO}

The thickness of the $\mathrm{Cu}_{2} \mathrm{Cl}(\mathrm{OH})_{3}$ shell layer was controlled by either changing the reaction time or using a different concentration of $\mathrm{CuCl}_{2}$, as presented in Figure S1 (Supplementary Material). For example, increasing the reaction time from $45 \mathrm{~min}$ to $7 \mathrm{~h}$ leads to an increase in the shell thickness, from 1-2 $\mu \mathrm{m}$ to several $\mu \mathrm{m}(5-10 \mu \mathrm{m})$. In comparison, keeping the same reaction time and reducing the $\mathrm{CuCl}_{2}$ amount to $25 \mathrm{mg}$ results in the formation of a shell with a thickness of ca. $500 \mathrm{~nm}$.

Most often, to produce metal oxides in aqueous solutions, two-step syntheses are used. Usually, the direct product, the metal-based hydroxide, undergoes a conversion process to form the metal oxide [23-25,27,28,42]. Figure 4 shows the structural characterization of the $3 \mathrm{D}$ structure after the effective conversion of $\mathrm{Cu}_{2} \mathrm{Cl}(\mathrm{OH})_{3}$ to copper oxide $\left(\mathrm{CuO}_{\text {or }} \mathrm{Cu}_{2} \mathrm{O}\right)$ by reduction or calcination, respectively. Sorites@CuO was formed after annealing the Sorites@ $\mathrm{Cu}_{2} \mathrm{Cl}(\mathrm{OH})_{3}$ at $400{ }^{\circ} \mathrm{C}$ for 2 h under air. Sorites@ $\mathrm{Cu}_{2} \mathrm{O}$ was formed after reacting the Sorites@ $\mathrm{Cu}_{2} \mathrm{Cl}(\mathrm{OH})_{3}$ with hydrazine for several minutes. The 3D morphology was preserved after the conversion processes, as shown in the optical and SEM images in Figure $4 a, b, d, e$. The color change (from turquoise to black or red-orange) and the obtained XRD pattern endorse the successful transformation of the orthorhombic $\mathrm{Cu}_{2} \mathrm{Cl}(\mathrm{OH})_{3}$ to the respective copper oxide phase. According to a previous work [35], heating Sorites at high temperatures results in the formation of an additional phase $\left(\mathrm{CaCO}_{3}\right)$ alongside the rhombohedral $\mathrm{Mg}_{0.1} \mathrm{Ca}_{0.9} \mathrm{CO}_{3}$. Figure 4c shows that after calcination, the obtained diffraction matches with rhombohedral $\mathrm{Mg}_{0.1} \mathrm{Ca}_{0.9} \mathrm{CO}_{3}$ (JCPDS card no. 071-1663), rhombohedral $\mathrm{CaCO}_{3}$ (JCPDS card no. 005-0586), and monoclinic copper(I) oxide (CuO, JCPDS card no. 045-0937). After a reduction process, the achieved XRD pattern is assigned to rhombohedral $\mathrm{Mg}_{0.1} \mathrm{Ca}_{0.9} \mathrm{CO}_{3}$ and cubic copper(II) oxide $\left(\mathrm{Cu}_{2} \mathrm{O}\right.$, JCPDS card no. 065-3288), as shown in Figure 4f. Furthermore, the absence of $\mathrm{Cu}_{2} \mathrm{Cl}(\mathrm{OH})_{3}$ diffraction signal confirms a complete structural conversion. 

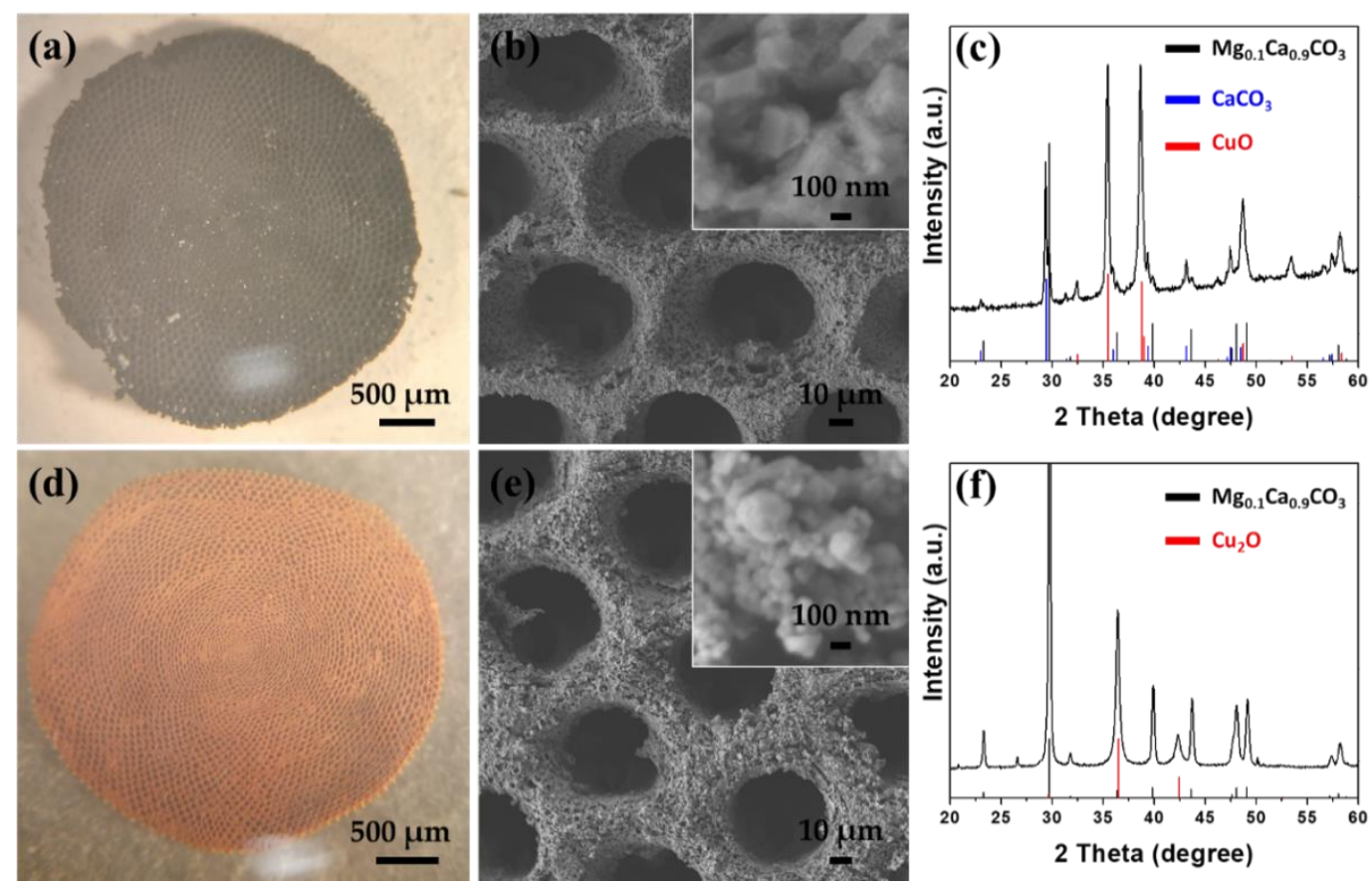

Figure 4. Structural characterization of the 3D structure after converting the hydroxide shell to an oxide. (a,d) The optical images, (b,e) SEM images, and (c,f) XRD patterns of Sorites@CuO and Sorites@ $\mathrm{Cu}_{2} \mathrm{O}$, respectively. The black, blue, and red stick patterns in the XRD panels correspond to the rhombohedral $\mathrm{Mg}_{0.1} \mathrm{Ca}_{0.9} \mathrm{CO}_{3}$, rhombohedral $\mathrm{CaCO}_{3}$, and the coated materials, respectively.

2.3. Potential Application of Sorites@CuO in the Removal of Heavy Metal Ions and Degradation of an Organic Model Dye Molecule

We demonstrate the activity of the proposed system in this work by removing heavy metal cations $\left(\mathrm{Pb}^{2+}\right.$ and $\left.\mathrm{Cd}^{2+}\right)$ from water and in the degradation of methylene blue (MB). In our previous work, we have shown the contribution of the porous 3D structure (Soritesbased) relative to their $2 \mathrm{D}$ counterparts [36]. Based on these results, we have chosen to deposit the active copper oxides on the porous structures. Reacting the Sorites@CuO with a metal-containing solution leads to a significant reduction in the concentration of metal cations. The concentrations of $\mathrm{Pb}^{2+}\left(\mathrm{Cd}^{2+}\right)$ dropped from $122 \mathrm{ppm}$ (98 ppm) to $4.8 \mathrm{ppm}$ (0.21 ppm), which corresponds to a purification of $96 \%(99.7 \%)$.

It is important to point out that the mass of copper oxide is around $17 \%$ of the total mass of the formed 3D structure. Thus, the adsorption capacity of the active material $(\mathrm{CuO})$ for $\mathrm{Pb}^{2+}$ and $\mathrm{Cd}^{2+}$ is $78 \mathrm{mg} / \mathrm{g}$ and $66 \mathrm{mg} / \mathrm{g}$, respectively. These values are lower than the reported values for $\mathrm{Pb}^{2+}(115-125)$ and $\mathrm{Cd}^{2+}(192)[9,16]$. This difference can be attributed to the relatively thick coating layer of $\mathrm{CuO}$.

To rule out the formation of metal hydroxide as the reason for the removal of $\mathrm{Pb}^{2+}$ and $\mathrm{Cd}^{2+}$, we made sure that the $\mathrm{pH}$ of the heavy metal cation solution is not sufficient to lead to precipitation of the metal hydroxides (Equations (4) and (5)). At room temperature, precipitation ensues at a $\mathrm{pH}$ value calculated using Equation (6).

$$
\begin{aligned}
\mathrm{Pb}(\mathrm{OH})_{2}(\mathrm{~s}) & \rightleftharpoons \mathrm{Pb}^{2+}(\mathrm{aq})+2 \mathrm{OH}^{-}(\mathrm{aq}) \\
\mathrm{Cd}(\mathrm{OH})_{2}(\mathrm{~s}) & \rightleftharpoons \mathrm{Cd}^{2+}(\mathrm{aq})+2 \mathrm{OH}^{-}(\mathrm{aq}) \\
\mathrm{pH} & =14-\log \frac{\sqrt{\left[\mathrm{M}^{2+}\right]}}{\sqrt{K_{\mathrm{sp}}}}
\end{aligned}
$$


The solubility of lead and cadmium hydroxide is $1 \times 10^{-16}$ and $7.2 \times 10^{-15}$, respectively $[10,41]$. Thus, to precipitate a $\mathrm{Pb}(\mathrm{OH})_{2}$ or $\mathrm{Cd}(\mathrm{OH})_{2}$ starting with $\left[\mathrm{Pb}^{2+}\right]=0.59 \mu \mathrm{M}$ or $\left[\mathrm{Cd}^{2+}\right]=0.87 \mu \mathrm{M}$, a pH value of 7.6 or 8.5 is required, respectively. However, in the described case, the $\mathrm{pH}$ of the heavy metal solutions was 6 , which confirms that the removal of the cation is attributed to the action of $\mathrm{CuO}$.

Figure $5 \mathrm{~b}$ presents a model organic dye degradation reaction in an aqueous solution containing $\mathrm{MB}$ molecules using $\mathrm{H}_{2} \mathrm{O}_{2}$ only (black), Sorites@CuO only (red), and Sorites@CuO in the presence of $\mathrm{H}_{2} \mathrm{O}_{2}$ (blue). The addition of $\mathrm{H}_{2} \mathrm{O}_{2}$ to the MB solution reduces the concentration of the dye by $15 \%$, and a plateau is observed around $C / C_{0}=0.85$. When a Sorites@CuO catalyst was used, a 50 min incubation with MB solution was carried out to reach an adsorption-desorption equilibrium before monitoring the degradation reaction. After 50 min of incubation, the MB concentration reached about half of its initial value. Then, a slow decrease in concentration was observed, reaching a relative concentration of 0.42 after $70 \mathrm{~min}$ (degradation of $\sim 20 \%$ relative to $t=0$ ). The addition of $\mathrm{H}_{2} \mathrm{O}_{2}$ to an MB solution that contains the Sorites@CuO, after reaching a similar adsorption-desorption equilibrium, allowed the successful degradation of more than $98 \%$ of the initial MB after $70 \mathrm{~min}$ (blue line). This significant improvement can be assigned to the reaction between $\mathrm{MB}$ and the formed radicals. Previous work suggests that the result of $\mathrm{H}_{2} \mathrm{O}_{2}$ addition to a solution that contains $\mathrm{CuO}$ is the formation of several radicals such as $\cdot \mathrm{OH}$ (for oxidation) and $\cdot \mathrm{O}_{2}$ (for reduction) [25]. Furthermore, Figure $\mathrm{S} 2$ shows that the Sorites@CuO with $\mathrm{H}_{2} \mathrm{O}_{2}$ enables the reduction of the concentration of other dyes, specifically rhodamines- $\mathrm{Rh} 6 \mathrm{G}$ and $\mathrm{RhB}-$ to $11 \%$ and $36 \%$ of their respective initial concentrations.
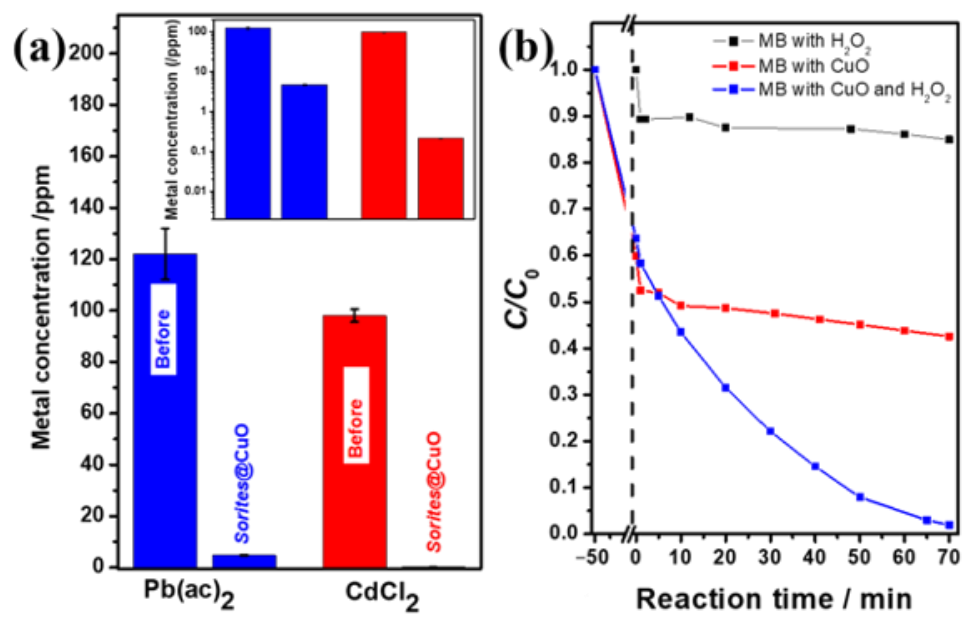

Figure 5. The performance of Sorites@CuO in water purification processes. (a) Different concentrations of $\mathrm{Pb}^{2+}$ (blue bars) and $\mathrm{Cd}^{2+}$ (red bars) were removed from the water by the Sorites@CuO 3D structure. The inset shows the concentrations of the $\mathrm{Pb}^{2+}$ and $\mathrm{Cd}^{2+}$ before and after removal using a logarithmic scale. (b) MB dye molecule degradation using Sorites@CuO. Complete degradation (blue) is achieved when the dye is mixed with both $\mathrm{H}_{2} \mathrm{O}_{2}$ and Sorites@CuO; two control conditions: degradation experiment (black) where the dye is mixed with $\mathrm{H}_{2} \mathrm{O}_{2}$ only; adsorption experiment (red) where the dye is mixed with Sorites@CuO only.

\section{Materials and Methods}

\subsection{Materials}

Cadmium (II) chloride $\left(\mathrm{CdCl}_{2}, 99+\%\right)$, copper (II) acetate $\left(\mathrm{Cu}(\mathrm{ac})_{2}, 99 \%\right)$, copper (II) chloride $\left(\mathrm{CuCl}_{2}, 98 \%\right)$, copper (II) nitrate trihydrate $\left(\mathrm{Cu}\left(\mathrm{NO}_{3}\right)_{2} \cdot 3 \mathrm{H}_{2} \mathrm{O}, 99.5 \%\right)$, copper (II) sulfate $\left(\mathrm{CuSO}_{4}, 98 \%\right)$, and lead (II) acetate trihydrate $\left(\mathrm{Pb}(\mathrm{ac})_{2} \cdot 3 \mathrm{H}_{2} \mathrm{O}, 99.999 \%\right)$ were purchased from Strem Chemicals (Newburyport, MA, USA). Hydrazine monohydrate (98\%), hydrogen peroxide $\left(\mathrm{H}_{2} \mathrm{O}_{2}, 30 \% \mathrm{wt}\right.$.), methylene blue (MB), and rhodamine 6G (Rh6G, 95\%) were purchased from Sigma-Aldrich (St. Louis, MI, USA). Sodium hypochlorite (11-14\% wt. available chlorine, assay result (iodometric titration) of $11.8 \% \mathrm{wt}$.) and rho- 
damine B (RhB) were purchased from Alfa Aesar (Heysham, Lancashire, UK). Hydrochloric acid $(\mathrm{HCl}, 32 \% \mathrm{wt}$.) was purchased from Bio-Lab (Jerusalem, Israel). All reagents were used as received without further purification. Deionized (DI) water was purified using a Millipore Direct-Q system (18.2 $\mathrm{M} \Omega \mathrm{cm}$ resistivity).

\subsection{Purification and Pretreatment of Sorites Bio-Template}

The Sorites bio-templates were collected from the red sea (Interuniversity Institute for Marine Sciences of Eilat) and were separated from other species by a sifting and washing process, as shown in Figure 6a. Figure $6 \mathrm{~b}$ shows the surface cleaning and the etching process. The Sorites species were immersed in a sodium hypochlorite solution $(12 \% \mathrm{wt}$. $\mathrm{OCl}^{-}$) for two hours. Finally, the top layer of the Sorites template was removed by soaking in $0.05 \mathrm{M} \mathrm{HCl}$ solution for $3 \mathrm{~min}$.

\section{(a)}

(b)
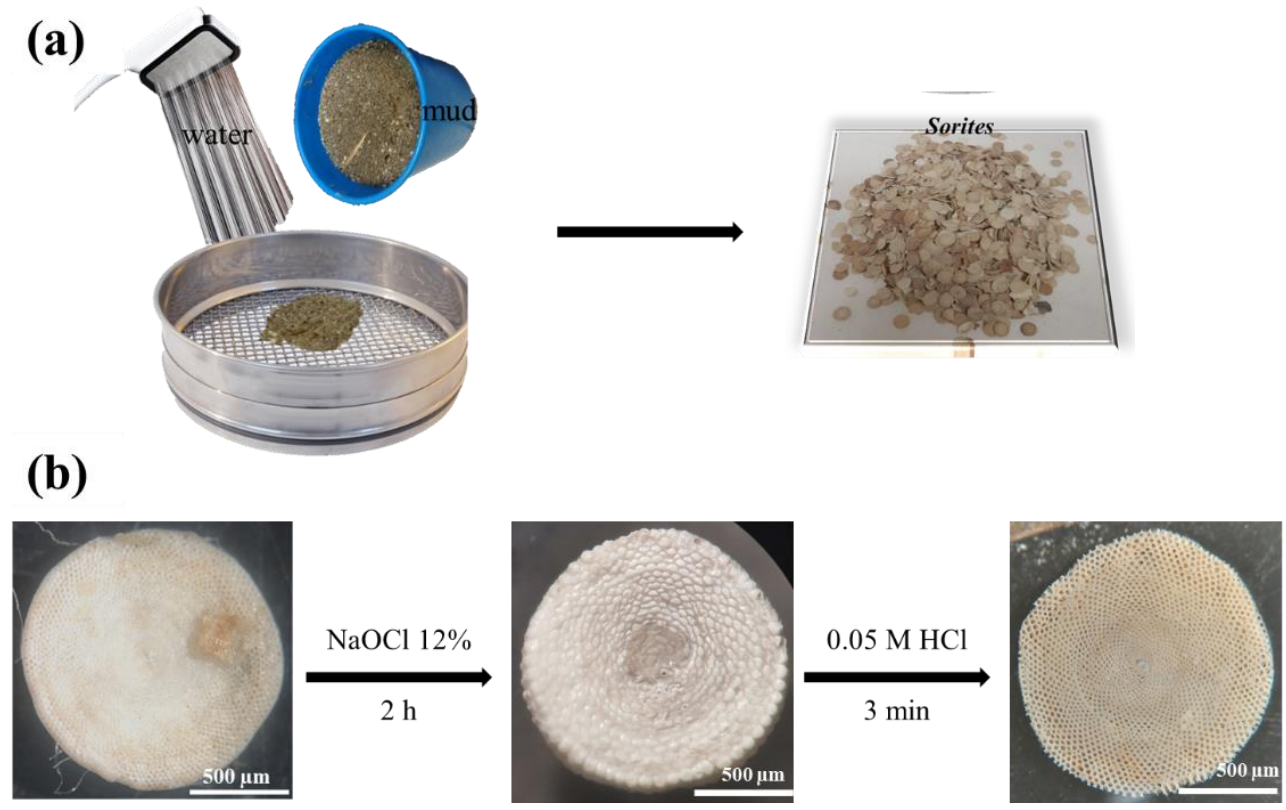

Figure 6. Purification and pretreatment processes of Sorites: (a) sifting and washing, (b) chemical pretreatment.

\subsection{Formation of a Copper Oxide Porous 3D Structure}

The Sorites species $(30 \mathrm{mg}$ ) were placed perpendicular to the substrate using carbon tape, as shown in Figure 1a. The substrate was diagonally placed inside a PTFE-lined autoclave ( $25 \mathrm{~mL}$ container), which contains $7 \mathrm{~mL}$ of $0.21 \mathrm{M}$ copper (II) solution $\left(\mathrm{Cu}(\mathrm{ac})_{2}\right.$, $\mathrm{CuCl}_{2}$, or $\left.\mathrm{Cu}\left(\mathrm{NO}_{3}\right)_{2}\right)$. Subsequently, the autoclave was heated to $120^{\circ} \mathrm{C}$ for $45 \mathrm{~min}$. The products (Sorites coated hydroxide-based material, Figure $1 \mathrm{~b}$ ) were washed with water and dried at $60{ }^{\circ} \mathrm{C}$. The Sorites@ $\mathrm{Cu}_{2} \mathrm{Cl}(\mathrm{OH})_{3}$ was annealed at $400{ }^{\circ} \mathrm{C}$ for $2 \mathrm{~h}$ under air (heating rate of $10^{\circ} \mathrm{C} \mathrm{min}^{-1}$ from room temperature to the target temperature) to form the Sorites@CuO.Sorites@ $\mathrm{Cu}_{2} \mathrm{O}$ was obtained by adding $100 \mu \mathrm{L}$ of hydrazine solution to the copper-based hydroxide and reacting for $5 \mathrm{~min}$.

\subsection{Removal of Heavy Metal Ions}

Forty $\mathrm{mL}$ of contaminated solution was prepared using DI water and $\mathrm{Pb}(\mathrm{ac})_{2} \cdot 3 \mathrm{H}_{2} \mathrm{O}$ $(16 \mathrm{mg})$ or $\mathrm{CdCl}_{2}(7 \mathrm{mg})$. Atomic absorption spectroscopy (AAS, Perkin Elmer Analyst 400, PerkinElmer, Inc., Waltham, MA, USA) was used to measure the concentration of $10 \mathrm{~mL}$ of $\mathrm{Pb}^{2+}$ and $\mathrm{Cd}^{2+}$ solutions before and after reacting with Sorites@CuO 3D structure. The concentration of the prepared heavy metal solution was $122 \mathrm{ppm} \mathrm{of} \mathrm{Pb}^{2+}$ (Figure 5a, blue bar) and 98 ppm of $\mathrm{Cd}^{2+}$ (Figure 5a, red bar). Sorites@CuO (100 mg) was shaken with $10 \mathrm{~mL}$ of $\mathrm{Pb}^{2+}$ or $\mathrm{Cd}^{2+}$ solutions for one hour at room temperature. The $\mathrm{pH}$ of the prepared solution was low $\left(\mathrm{pH}\right.$ 6) to prevent the possible precipitation of $\mathrm{Pb}(\mathrm{OH})_{2}$ or $\mathrm{Cd}(\mathrm{OH})_{2}$. 
The AAS measurements of concentrations (both before and after the removal process) were repeated three times to calculate the standard deviation. Before each measurement, a calibration curve was performed using standard solutions, and each sample was filtered with a $0.22 \mu \mathrm{m}$ PVDF syringe filter.

\subsection{Dye Degradation}

Stock solutions of dye molecules (MB, RhB, or Rh6G) were prepared by dissolving the powdered dyes in DI water. The concentrations were adjusted such that the O.D. at $664 \mathrm{~nm}$ was $\sim 1$ for MB, O.D. at $554 \mathrm{~nm}$ was $\sim 1.45$ for RhB, and O.D. at $526 \mathrm{~nm}$ was $\sim 1.12$ for Rh6G. Sorites@CuO (60 mg) was incubated with $6 \mathrm{~mL}$ of the respective dye solution for 50 min under dark conditions at room temperature to achieve an adsorption-desorption equilibrium between the dye and the surface of the porous $3 \mathrm{D}$ structure. When $\mathrm{H}_{2} \mathrm{O}_{2}$ was used, the incubation was followed by the addition of $340 \mu \mathrm{L}$ of $\mathrm{H}_{2} \mathrm{O}_{2}$ solution (30\% wt.). $\mathrm{UV}$ - vis absorbance values were used to examine the change in the dye absorbance at $\lambda_{\max }$ $\left(\mathrm{MB}-664 \mathrm{~nm}, \mathrm{RhB}-554 \mathrm{~nm}\right.$, and Rh6G-526 nm) and calculation of $C / C_{0}$.

\subsection{Structural Characterization}

Scanning electron microscopy (SEM) was performed using a JEOL JSM-7400F highresolution SEM system with a cold field emission gun, which was operated at $3.5 \mathrm{kV}$. Energy-dispersive X-ray spectroscopy (EDS) analysis was conducted using an SEM-coupled Thermo Scientific Noran SIX system at an accelerating voltage of $15.0 \mathrm{kV}$. Phase analysis of the samples was carried out using the X-ray diffraction (XRD) method. The data was collected on an Empyrean powder diffractometer (Malvern Panalytical, Worcestershire, $\mathrm{UK}$ ) equipped with a position-sensitive $X^{\prime}$ Celerator detector using $\mathrm{Cu} \mathrm{K} \alpha$ radiation $(\lambda=1.5418 \AA)$, operated at $40 \mathrm{kV}$ and $30 \mathrm{~mA}$. Optical absorbance measurements were made using a Cary 5000 UV - vis-NIR spectrophotometer using standard $10 \mathrm{~mm}$ quartz cuvettes.

\section{Conclusions}

A simple approach for the formation of porous 3D structures of copper oxides $(\mathrm{CuO}$, $\mathrm{Cu}_{2} \mathrm{O}$ ) and copper-based hydroxides using the template method was demonstrated. It is found that the counter anion plays an essential role both in the formation of the 3D structure and in the formation of the copper-based hydroxide coating. The Sorites scaffold has two functions: (i) serving as the template for the structure and (ii) forming a local basic environment, which allows the precipitation of copper hydroxide throughout the porous structure. To allow the local hydroxide precipitation, the initial $\mathrm{pH}$ of the growth solution has to be low enough (i.e., 4 when chloride or nitrate counterions were used) to allow the partial dissolution of the $\mathrm{CaCO}_{3}$ template, releasing free hydroxide anions. These, in turn, allow the formation of the copper hydroxide throughout the porous 3D structure of the template, resulting in its coating. The copper oxide $\left(\mathrm{CuO}\right.$ or $\left.\mathrm{Cu}_{2} \mathrm{O}\right) 3 \mathrm{D}$ structures were formed in a subsequent step (by calcination or reduction, respectively). Finally, the prepared $\mathrm{CuO}$ structure allows the removal of more than $96 \%$ of heavy metal cations and degradation of more than $98 \%$ of an organic dye molecule.

Supplementary Materials: The following are available online: Figure S1: SEM images of Sorites@ $\mathrm{Cu}_{2} \mathrm{Cl}(\mathrm{OH})_{3}$ obtained after reacting the Sorites $(\mathrm{a}, \mathrm{b})$ with $25 \mathrm{mg}$ of $\mathrm{CuCl}_{2}$ at $120{ }^{\circ} \mathrm{C}$ for $45 \mathrm{~min}$ and (c,d) with $200 \mathrm{mg}$ of $\mathrm{CuCl}_{2}$ at $120{ }^{\circ} \mathrm{C}$ for $7 \mathrm{~h}$. Figure S2: Degradation of (a) RhB and (b) Rh6G using different catalysts. The vertical black dashed lines show the time of degradation initiation $(t=0)$. Black: the dyes were mixed with $\mathrm{H}_{2} \mathrm{O}_{2}$ only; red: the dyes were mixed with the Sorites@CuO only; blue: the dyes were mixed with both $\mathrm{H}_{2} \mathrm{O}_{2}$ and Sorites@CuO.

Author Contributions: Conceptualization, M.D. and T.M.; methodology, M.D. and K.S.; validation, M.D., M.V. and T.M.; formal analysis, M.D. and K.S.; investigation, M.D.; resources, T.M.; data curation, M.D., M.V. and T.M.; writing—original draft preparation, M.D.; writing—review and editing, M.D., M.V. and T.M.; visualization, M.D.; supervision, T.M.; project administration, M.V.; funding acquisition, T.M. All authors have read and agreed to the published version of the manuscript. 
Funding: This research received no external funding.

Institutional Review Board Statement: Not applicable.

Informed Consent Statement: Not applicable.

Data Availability Statement: The data presented in this study are available on request from the corresponding author.

Acknowledgments: We thank the Interuniversity Institute for Marine Sciences of Eilat, Israel, for the logistic support of the Sorites-related field work.

Conflicts of Interest: The authors declare no conflict of interest.

Sample Availability: Samples of the compounds are available from the authors.

\section{References}

1. World Health Organization. Available online: https://www.who.int/news-room/fact-sheets/detail/drinking-water (accessed on 1 September 2021).

2. Hashim, M.A.; Mukhopadhyay, S.; Sahu, J.N.; Sengupta, B. Remediation technologies for heavy metal contaminated groundwater. J. Environ. Manag. 2011, 92, 2355-2388. [CrossRef] [PubMed]

3. Barakat, M.A. New trends in removing heavy metals from industrial wastewater. Arab. J. Chem. 2011, 4, 361-377. [CrossRef]

4. Gupta, V.K.; Ali, I.; Saleh, T.A.; Nayak, A.; Agarwal, S. Chemical treatment technologies for waste-water recycling-An overview. RSC Adv. 2012, 2, 6380-6388. [CrossRef]

5. Dongare, P.D.; Alabastri, A.; Pedersen, S.; Zodrow, K.R.; Hogan, N.J.; Neumann, O.; Wu, J.; Wang, T.; Deshmukh, A.; Elimelech, M.; et al. Nanophotonics-enabled solar membrane distillation for off-grid water purification. Proc. Natl. Acad. Sci. USA 2017, 114, 6936-6941. [CrossRef] [PubMed]

6. Kaufman, Y.; Berman, A.; Freger, V. Supported lipid bilayer membranes for water purification by reverse osmosis. Langmuir 2010, 26, 7388-7395. [CrossRef] [PubMed]

7. Reed, B.E.; Vaughan, R.; Jiang, L. As(III), As(V), Hg, and Pb Removal by Fe-Oxide Impregnated Activated Carbon. J. Environ. Eng. 2000, 126, 869-873. [CrossRef]

8. Sakamoto, T.; Ogawa, T.; Nada, H.; Nakatsuji, K.; Mitani, M.; Soberats, B.; Kawata, K.; Yoshio, M.; Tomioka, H.; Sasaki, T.; et al. Development of Nanostructured Water Treatment Membranes Based on Thermotropic Liquid Crystals: Molecular Design of Sub-Nanoporous Materials. Adv. Sci. 2018, 5, 1700405. [CrossRef] [PubMed]

9. Farghali, A.A.; Bahgat, M.; Enaiet Allah, A.; Khedr, M.H. Adsorption of $\mathrm{Pb}(\mathrm{II})$ ions from aqueous solutions using copper oxide nanostructures. Beni-Suef Univ. J. Basic Appl. Sci. 2013, 2, 61-71. [CrossRef]

10. Raul, P.K.; Senapati, S.; Sahoo, A.K.; Umlong, I.M.; Devi, R.R.; Thakur, A.J.; Veer, V. CuO nanorods: A potential and efficient adsorbent in water purification. RSC Adv. 2014, 4, 40580-40587. [CrossRef]

11. Hua, M.; Zhang, S.; Pan, B.; Zhang, W.; Lv, L.; Zhang, Q. Heavy metal removal from water/wastewater by nanosized metal oxides: A review. J. Hazard. Mater. 2012, 211-212, 317-331. [CrossRef]

12. Liu, Y.; Li, Q.; Gao, S.; Shang, J.K. Exceptional As(III) sorption capacity by highly porous magnesium oxide nanoflakes made from hydrothermal synthesis. J. Am. Ceram. Soc. 2011, 94, 217-223. [CrossRef]

13. Li, L.H.; Xiao, J.; Liu, P.; Yang, G.W. Super adsorption capability from amorphousization of metal oxide nanoparticles for dye removal. Sci. Rep. 2015, 5, 9028. [CrossRef]

14. Krivec, M.; Žagar, K.; Suhadolnik, L.; Čeh, M.; Dražić, G. Highly efficient $\mathrm{TiO}_{2}$-based microreactor for photocatalytic applications. ACS Appl. Mater. Interfaces 2013, 5, 9088-9094. [CrossRef] [PubMed]

15. Gupta, V.K.; Chandra, R.; Tyagi, I.; Verma, M. Removal of hexavalent chromium ions using CuO nanoparticles for water purification applications. J. Colloid Interface Sci. 2016, 478, 54-62. [CrossRef] [PubMed]

16. Bhanjana, G.; Dilbaghi, N.; Singhal, N.K.; Kim, K.H.; Kumar, S. Copper oxide nanoblades as novel adsorbent material for cadmium removal. Ceram. Int. 2017, 43, 6075-6081. [CrossRef]

17. Roy Choudhury, P.; Majumdar, S.; Sahoo, G.C.; Saha, S.; Mondal, P. High pressure ultrafiltration CuO/hydroxyethyl cellulose composite ceramic membrane for separation of $\mathrm{Cr}(\mathrm{VI})$ and $\mathrm{Pb}$ (II) from contaminated water. Chem. Eng. J. 2018, 336, 570-578. [CrossRef]

18. Choudhury, P.; Mondal, P.; Majumdar, S.; Saha, S.; Sahoo, G.C. Preparation of ceramic ultrafiltration membrane using green synthesized $\mathrm{CuO}$ nanoparticles for chromium (VI) removal and optimization by response surface methodology. J. Clean. Prod. 2018, 203, 511-520. [CrossRef]

19. Khew, S.Y.; Tan, C.F.; Yan, H.; Lin, S.; Thian, E.S.; Zhou, R.; Hong, M. Nanosecond laser ablation for enhanced adhesion of CuO nanowires on copper substrate and its application for oil-water separation. Appl. Surf. Sci. 2019, 465, 995-1002. [CrossRef]

20. Silva Junior, O.J.; Monteiro, A.F.F.; Oliveira, J.B.L.; Araújo, A.M.U.; Silva, D.G.; Kulesza, J.; Barros, B.S. Coordination polymerderived $\mathrm{CuO}$ catalysts for oxidative degradation of methylene blue. Mater. Chem. Phys. 2019, 235, 121737-121744. [CrossRef]

21. Yang, M.; He, J. Fine tuning of the morphology of copper oxide nanostructures and their application in ambient degradation of methylene blue. J. Colloid Interface Sci. 2011, 355, 15-22. [CrossRef] 
22. Devi, H.; Singh, D. Synthesis of Copper Oxide Nanoparticles by a Novel Method and its Application in the Degradation of Methyl Orange. Adv. Electron. Electr. Eng. 2014, 4, 83.

23. Karim, M.N.; Singh, M.; Weerathunge, P.; Bian, P.; Zheng, R.; Dekiwadia, C.; Ahmed, T.; Walia, S.; Della Gaspera, E.; Singh, S.; et al. Visible-Light-Triggered Reactive-Oxygen-Species-Mediated Antibacterial Activity of Peroxidase-Mimic CuO Nanorods. ACS Appl. Nano Mater. 2018, 1, 1694-1704. [CrossRef]

24. Yecheskel, Y.; Dror, I.; Berkowitz, B. Catalytic degradation of brominated flame retardants by copper oxide nanoparticles. Chemosphere 2013, 93, 172-177. [CrossRef]

25. Černík, M.; Thekkae Padil, V.V. Green synthesis of copper oxide nanoparticles using gum karaya as a biotemplate and their antibacterial application. Int. J. Nanomed. 2013, 8, 889. [CrossRef] [PubMed]

26. Wongpisutpaisan, N.; Charoonsuk, P.; Vittayakorn, N.; Pecharapa, W. Sonochemical synthesis and characterization of copper oxide nanoparticles. Energy Procedia 2011, 9, 404-409. [CrossRef]

27. Phiwdang, K.; Suphankij, S.; Mekprasart, W.; Pecharapa, W. Synthesis of CuO nanoparticles by precipitation method using different precursors. Energy Procedia 2013, 34, 740-745. [CrossRef]

28. Chang, Y.; Zeng, H.C. Controlled synthesis and self-assembly of single-crystalline CuO nanorods and nanoribbons. Cryst. Growth Des. 2004, 4, 397-402. [CrossRef]

29. Moosavifard, S.E.; El-Kady, M.F.; Rahmanifar, M.S.; Kaner, R.B.; Mousavi, M.F. Designing 3D highly ordered nanoporous CuO electrodes for high-performance asymmetric supercapacitors. ACS Appl. Mater. Interfaces 2015, 7, 4851-4860. [CrossRef]

30. Wang, C.; Yue, L.; Wang, S.; Pu, Y.; Zhang, X.; Hao, X.; Wang, W.; Chen, S. Role of Electric Field and Reactive Oxygen Species in Enhancing Antibacterial Activity: A Case Study of 3D Cu Foam Electrode with Branched CuO-ZnO NWs. J. Phys. Chem. C 2018, 122, 26454-26463. [CrossRef]

31. Shen, L.; Ali, M.; Gu, Z.; Min, B.; Kim, D.; Park, C. Preparation of anodic aluminum oxide (AAO) nano-template on silicon and its application to one-dimensional copper nano-pillar array formation. Korean J. Chem. Eng. 2013, 30, 221-227. [CrossRef]

32. Crick, C.R.; Parkin, I.P. CVD of copper and copper oxide thin films via the in situ reduction of copper(ii) nitrate-A route to conformal superhydrophobic coatings. J. Mater. Chem. 2011, 21, 14712-14716. [CrossRef]

33. Diab, M.; Moshofsky, B.; Jen-La Plante, I.; Mokari, T. A facile one-step approach for the synthesis and assembly of copper and copper-oxide nanocrystals. J. Mater. Chem. 2011, 21, 11626. [CrossRef]

34. Diab, M.; Mokari, T. Bioinspired Hierarchical Porous Structures for Engineering Advanced Functional Inorganic Materials. Adv. Mater. 2018, 30, 1706349. [CrossRef] [PubMed]

35. Diab, M.; Shreteh, K.; Afik, N.; Volokh, M.; Abramovich, S.; Abdu, U.; Mokari, T. Design of Hierarchal 3D Metal Oxide Structures for Water Oxidation and Purification. Adv. Sustain. Syst. 2018, 2, 1800001. [CrossRef]

36. Diab, M.; Shreteh, K.; Volokh, M.; Abramovich, S.; Abdu, U.; Mokari, T. Calcareous Foraminiferal Shells as a Template for the Formation of Hierarchal Structures of Inorganic Nanomaterials. ACS Appl. Mater. Interfaces 2019, 11, 6456-6462. [CrossRef]

37. Pan, L.; Zou, J.J.; Zhang, T.; Wang, S.; Li, Z.; Wang, L.; Zhang, X. $\mathrm{Cu}_{2} \mathrm{O}$ film via hydrothermal redox approach: Morphology and photocatalytic performance. J. Phys. Chem. C 2014, 118, 16335-16343. [CrossRef]

38. Švarcová, S.; Klementová, M.; Bezdička, P.; Śasocha, W.; Dušek, M.; Hradil, D. Synthesis and characterization of single crystals of the layered copper hydroxide acetate $\mathrm{Cu}_{2}(\mathrm{OH})_{3}\left(\mathrm{CH}_{3} \mathrm{COO}\right) \cdot \mathrm{H}_{2} \mathrm{O}$. Cryst. Res. Technol. 2011, 46, 1051-1057. [CrossRef]

39. Chen, L.; Zhang, Y.; Zhu, P.; Zhou, F.; Zeng, W.; Lu, D.D.; Sun, R.; Wong, C. Copper Salts Mediated Morphological Transformation of $\mathrm{Cu}_{2} \mathrm{O}$ from Cubes to Hierarchical Flower-like or Microspheres and Their Supercapacitors Performances. Sci. Rep. 2015, 5, 9672. [CrossRef] [PubMed]

40. Aguirre, J.M.; Gutiérrez, A.; Giraldo, O. Simple route for the synthesis of copper hydroxy salts. J. Braz. Chem. Soc. 2011, 22, 546-551. [CrossRef]

41. Lide, D.R. (Ed.) CRC Handbook of Chemistry and Physics: A Ready-Reference of Chemical and Physical Data, 85th ed.; CRC Press LLC: Boca Raton, FL, USA, 2004.

42. Diab, M.; Mokari, T. Role of the Counteranions on the Formation of Different Crystal Structures of Iron Oxyhydroxides via Redox Reaction. Cryst. Growth Des. 2017, 17, 527-533. [CrossRef] 